\title{
Importance of Palace Complexes, the Pearls of Medieval Islamic Architecture, in Urban Planning and Architecture
}

\author{
Shahla ABBASOVA ${ }^{1} 1$, Namiq ABBASOV (D) 1* \\ 1Burdur Mehmet Akif Ersoy University, Faculty of Engineering and Architecture, Department of Architecture, Burdur-Turkey \\ Geliş Tarihi (Received): 28.01.2021, Kabul Tarihi (Accepted): 21.05.2021 \\ $\square$ Sorumlu Yazar (Corresponding author ${ }^{\star}$ ): namiqabbasov@mehmetakif.edu.tr \\ (C) +902482132758 용 +902482132704
}

\begin{abstract}
Although the Islamic palace complexes considered the pearl of architecture, even though they are studied separately by scholars for years and centuries, their unity in one direction of architecture has been neglected so far. For this reason, we have tried to explore the architecture of palace complexes, which is considered to be the most beautiful examples of the magnificent Islamic architecture, to reveal their similar features, and to reflect the influence of these buildings on the formation and development of the urban planning composition. Palace complexes built in almost all the states that adopted Islam in the Middle Ages were planned to be the core of the city based on the same laws. The main purpose of the study is to explore the architecture, history and composition structure of the great Shirvanshahs, Topkapi Palace, Alhambra and Akbari Sarai palaces built in the Middle Ages and to reveal their similar features. In the study, it was proved that the architecture of the palace complexes that survived until today was built in the same styles, that Islam has its own architectural laws and that these laws are applied more accurately in palace construction.
\end{abstract}

Keywords: Composition, Islamic architecture, monumental buildings, ornament, palace

\section{Orta Çağ İslam Mimarisinin İncileri Olan Saray Komplekslerinin Şehir Planlaması ve Mimarisindeki Önemi}

ÖZ

Mimari inciler olan İslam saray kompleksleri, bilim adamları tarafından yüzyıllardır derinlemesine incelenmesine rağmen, mimariye entegrasyonlarına çok az ilgi gösterilmiştir. Bu sebeple araştırmada muhteşem İslam mimarisinin en güzel örnekleri olarak kabul edilen saray kompleksleri mimarisinin benzerlikleri ortaya çıkarılmaya, yapıların şehir planlama kompozisyonunun oluşumuna ve gelişimine etkisi yansıtılımaya çalışılmıştır. Orta Çağ'da İslam'ı benimseyen hemen hemen tüm ülkelerde inşa edilen saray kompleksleri, aynı mimari yasalara göre şehrin merkezi olarak planlanmaktaydı. Bu çalışmanın temel amacı, Orta Çağ'da inşa edilen gösterişli "Şirvanşahlar", "Topkapı", "Elhamra" ve "Ekber Sarayı" mimarisini, tarihini, kompozisyon yapısını incelemek ve benzer özelliklerini ortaya çıkarmaktır. Çaıışmada, günümüze kadar ulaşan saray komplekslerinin mimarisinin aynı tarzlarda inşa edildiği, İslam'ın kendine has mimari yasalarının olduğu ve bu yasaların saray yapımında daha doğru uygulandığı kanıtlanmıştır.

$\underline{\text { Anahtar Kelimeler: Kompozisyon, İslam mimarisi, anıtsal yapılar, süs, saray }}$ 


\section{INTRODUCTION}

It should be noted that palace architecture has been one of the highest peaks of architecture for centuries. The first use of many new forms and styles in architecture, mainly in the building of palaces, was not accidental and proved that these buildings are of great importance in architecture.

The main reason why the palace architecture is not only of architects but also of other spheres is that the palaces built by the rulers and feudal lords for centuries have always been based on the architecture of life and activity in accordance with the laws of magnificence and beauty, demonstrating their power with these architectural buildings. Such architectural form dates to the late Middle Ages, with a great development stage, and remnants of these architectural monuments remain around the world.

First, palatial buildings were ornate monumental buildings built for feudal lords and rulers, and then for people belonging to the higher strata of society. The word "palace" (Persian word "saray") means castle, residence. Besides castle and residence meanings, there are many synonyms of the word "saray" (immarat, pallaso). Although all these words have the same meaning, these buildings had different functions depending on the period and place.

It is important to note the distinctive nuances of the medieval eastern palaces differing from the European "northern" palaces. These nuances provided complete freedom for eastern fantasies, national tastes and local traditions to the palaces built in the Islamic architecture. In ancient times palaces in the East were kind of yard composition. A yard with fountain and a garden were the main organizational components here. The main characteristics of Islamic architecture in palace complexes such floral ornaments carved on the walls, fountains and stones were designed to imagine the palaces as the most beautiful places in the world.

The palaces, which were considered dominant in city structure in many periods, were built in Islamic countries more palatial in accordance with the modern requirements of the time in terms of architecture. Such palace complexes are Shirvanshahs $\left(15^{\text {th }}\right.$ Century, Baku-Azerbaijan), "Topkapi" (15 ${ }^{\text {th }}$ Century, IstanbulTurkey), Alhambra (1 $13^{\text {th }}$ Century, Granada-Spain) and Palace of Akbar (16 $6^{\text {th }}$ Century, Fatehpur Sikri-India). The construction period of the palace complexes combines them in one subject. The study of similarity of their architectural features proved that though the palatial architecture of other states built in the Middle
Ages has own peculiarities it reached its zenith by developing in the one architectural foundation. The fact that many of the palace complexes are in good condition until modern times prove the magnificence of their architecture.

\section{MATERIAL AND METHOD}

The scope of the study is to reveal the similar characteristics of the palace complexes built recently, which contribute to the world architectural heritage as important buildings of the Islamic World.

The palace complexes studied are mainly complexes, which are considered close analogs of Shirvanshah palace complexes, an architectural monument of Azerbaijan.

It should be noted that the analogs of the palace complexes in this direction so far have not been the subject of any study.

The similarity of architectural planning structures of "Shirvanshahs" (15 th Century, Baku-Azerbaijan), "Topkapi" (15 $5^{\text {th }}$ Century, Istanbul-Turkey), "Alhamra" (13 ${ }^{\text {th }}$ Century, Granada-Spain) and "Akbar sarai" (16 th Century, Fatehpur Sikri-India) palaces, which left a mark in the World architecture, means designing these structures on the basis of Islamic architectural laws.

First of all, it is of particular importance to pay attention to the construction of each of these complexes strategically in the highest places of the city. In the Middle Ages, according to the laws of architecture of the Islamic world, the Palace played a dominant role in the area where palace complexes were located. Cities have continuously developed around the Shahristan, where the palace complexes are located. For this reason, at the initial stage, the architecture of "inner castle" composition structures of many cities related to Islamic architecture was studied from historical sources.

Historical and architectural sources related to India's Mughal architecture have been analyzed in depth with Safavid architecture covering important periods of development of Azerbaijan in order to investigate the influence of some of the overthrown cities on Islamic palace architecture in Azerbaijan.

Images, plan structures, historical and architectural data of Turkish, Azerbaijani, Indian and Spanish palaces played a very important role in the study.

On the basis of these materials, confrontations were carried out in the palace buildings under investigation, 
and at the same time, the influence of Islamic religion on these buildings was revealed.

The research method consists of two stages;

1. The place of palace complexes in urban architecture in the Islamic World; the goals and methods of building "Ideal Cities" created by the constant development around the buildings of the Inner Fortress and their widespread use in the urban structure typical of the Islamic World are of great importance in the palace architecture in the section entitled the influence of palace architecture on the formation of the composition structure of Islamic cities of the Middle Ages.

2. In the section similar characteristics of the palace complexes of medieval Islamic states, the main plan of the palace buildings of Islamic architecture built in recent years, the structure of the composition, the designs analyze similar and different aspects of the styles and identify and discover important factors of their influence on each other.

\section{FINDINGS AND DISCUSSION}

The study consists of two sections. In the first section, it is discussed that the palace complexes have an important role in the process of establishing the "Ideal city" plan structure in the Islamic World. Designed as the core of the inner fortress, the building of the palace complexes was the planning structure of Muslim cities, and these cities were often built in irregular circular form. In the study, medieval Muslim cities such as Tabriz, Süleymaniye, Baghdad, Diyarbakir and Bukhara with such plan structure were examined as samples.

The second section of the study discusses similar architectural forms found in comparison with other important buildings of the Islamic World; "Shirvanshahs", "Topkapi", "Alhamra" and "Fatehpur Sikri" palaces are built in the Middle Ages. The reason for the discussions was the fact that the Shirvanshahs palace complexes, which is a monument of Azerbaijani architecture, caused many discussions during the construction of three courtyards. When discussing the findings that came out of this, our study mainly focused on the construction of the three courtyards of many palace complexes at the time.

The Topkapi Palace, which is considered the pearl of Turkish architecture, was first built in the $14^{\text {th }}$ Century in a three-storey plan structure. In this way, the structure of the plan is found in the period of Islamic architecture, Umayyad and Abbasid palace architecture. The reason for the division of the plan structure of the palace complexes into three parts is the result of the influence of Islamic religion.

The use of figures in architecture, which are of great importance in Islam, has always remained a mystery. In this verse of the Quran; "God has taken what is within them - science and counted everything one by one." (Cin, 72/28) As it has been known from this verse, many numbers in the holy book have special meaning. One of these figures was shown in Figure 3. As confirmation of this, the holy book finds its confirmation in the verses of the Holy Quran. The Quran tells Muslims about the three stages of nafs.

Many similar forms were used in the palace architecture of Akbar Shah, another analogue of the architecture of the Shirvanshah ensemble, considered the architectural jewel of India.

According to the study conducted over some discussions, Safavid architecture influenced Indian Islamic architecture.

The findings discussed in this study are quite clear to the discussions on why Indian architecture is so similar to Azerbaijani divankh.

\section{Influence of Palace Architecture on the Formation of the Composition Structure of Muslim Cities of the Middle Ages}

Each city is the highest level of architecture. The construction of buildings based on special rules even from ancient times. In general, the city itself is complex. During the formation of the first urban settlements in the World, when any town began to emerge, it developed continuously around a certain building that considered dominant. According to many historical resources, the emergence and sustainable development of cities since ancient times largely depended on the location of the palace complexes. These complexes played a key role in their planning, along with the fact that they dominated the plan structures of cities until the end of the Middle Ages.

It is still unknown the exact period and lands where the first cities were built. However, the existence of large cities is known to date back 4000 years ago. These were the cities of Egypt and Mesopotamia. Although the plans of these cities have not been reached until our time, the remains of individual monuments belonging to them remain until modern times (Gutnov and Glazychev, 1990). 
In Egypt (4000 BC), the form of residential buildings was based on the location of the palace complexes. According to the laws of Egypt, the gate of the houses of the people under the rule of the Pharaohs had to look in the direction of the Ruler's palace. As a result of frequent changes in the places of the residences of Pharaohs, the location of the residential buildings at the entrance had to be changed. This showed that the importance of palace buildings at that time was much higher than other buildings. In addition, as buildings were closer to each other in the cities in Egypt, the streets were narrow. Only the roads leading to the palaces and religious complexes had an open space.

For centuries, in the development phase of urbanization, especially in the Middle Ages, palace complexes dominated in Islamic cities and were the core of the construction. These buildings were built at the center of the city, mainly in strategically higher land areas.

The city, where palace complexes are located, was mainly considered the capital, so the development of these cities was even faster. As a result of the settlement of palace complexes at the core of such cities, sometimes the plans of cities were in a round form. According to the planning structure of such cities, they were called "Ideal cities" (Gutnov and Glazychev, 1990).

In the Middle Ages, such planning structures, that is, "Ideal cities", were more common in the Muslim states (Figure 1).

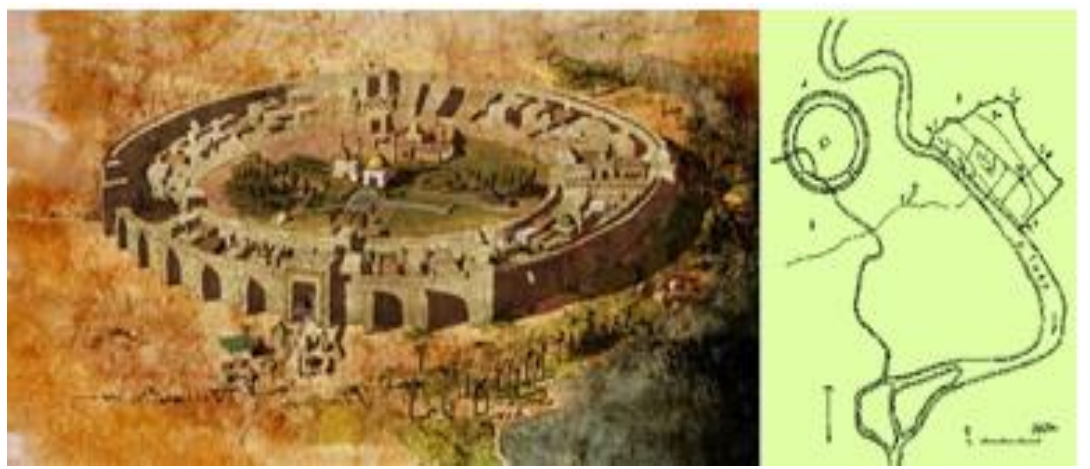

Figure 1. The City of Baghdad. The plan of 766-941 CE (Voronina, 1969)

The first core of Baghdad was founded by Abbasid Caliph al-Mansur in $762 \mathrm{CE}$ and completed in $766 \mathrm{CE}$ on the west coast of the Tigris, this round city was called Madinat as -Salam. It also meant a city of peace and tranquility. The Qasr al-Dhahab palace was in the center of plan structure of Baghdad and a mosque, other palaces and government bodies were around it, one of the most beautiful cities in the Eastern world. The central part of the city was assimilated with an oasis full of palm trees and was surrounded by a double fortress wall consisting of four doors (Abasov et al., 2010). The plan structure of this city was completely round, and its composition, along with revitalizing local urban traditions, led to a castle like temple-palace (Staradub, 2012).
One of the reasons of castle walls to be round as their construction required fewer financial resources, and from a strategic point of view, it was easy to protect such defensive structures.

Examples of such cities are cities of Tabriz and Suleymaniye, which developed and formed in the $13^{\text {th }}$ and $14^{\text {th }}$ centuries. The ancient miniaturists confirming that their plan structure was in the form of an incorrect circle are known to our history (Figure 2) (Yurdaydın, 1963). In 1534, when Matrakchi Nasuh was with Suleiman the Magnificent during his visits to Iraq and Iran, he described Tabriz as a circular form in miniature (Kuruju and Ozen, 2018). 

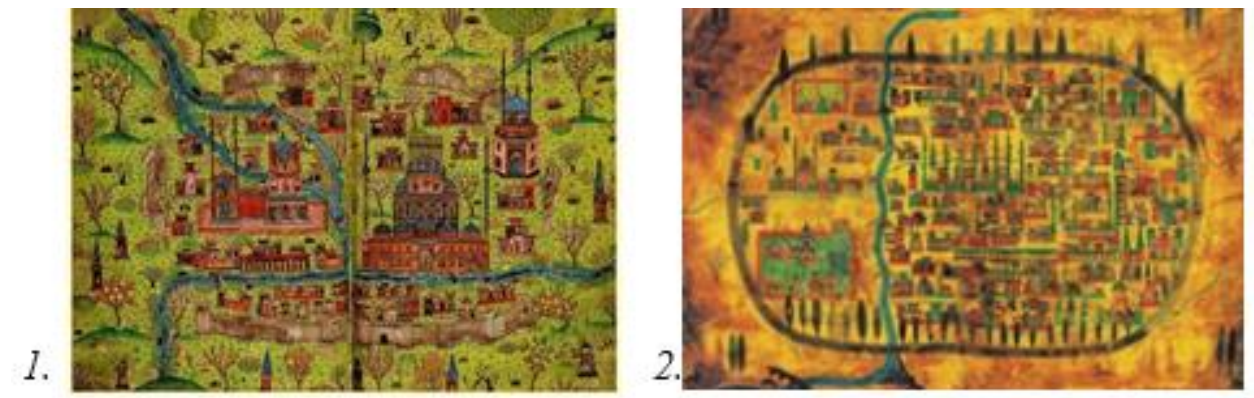

Figure 2. 1. Miniature of the city of Sultania, 2. Miniature of the city of Tabriz (Kuruju and Ozen, 2018)

Contemporaries of the period paid more attention to Tabriz, which was famous for its textile industry and became one of the major arts, trade and cultural centers of the East in a short period of time. Tabriz had been a citycastle yet before our era and had developed much more in the Middle Ages. In the $13^{\text {th }}$ and $14^{\text {th }}$ centuries, the gradual relocation of Elkhanids' residences to Tabriz in the first place created a great incentive for the development of this city (Useynov et al., 1963).

The city of Tabriz was surrounded by two or even threepart structure during Kazan Khan period with fortress walls built in its center up to Shahristan and Mongols (Figure 3) (Muradov, 1984). Characterizing some features of the architectural appearance of the city of Tabriz in the $13^{\text {th }}$ and $14^{\text {th }}$ centuries, it should be noted that the structure of its plan dominated by the radial-circular system, including complex and curved streets. The residence of Khan or his successor in the inner fortress was considered the central part of the city. Rich strata of the population and buildings belonging to "government bodies" were assembled around the citadel. Then were the neighborhoods where the craftsmen and the workers lived (Useynov et al., 1963).

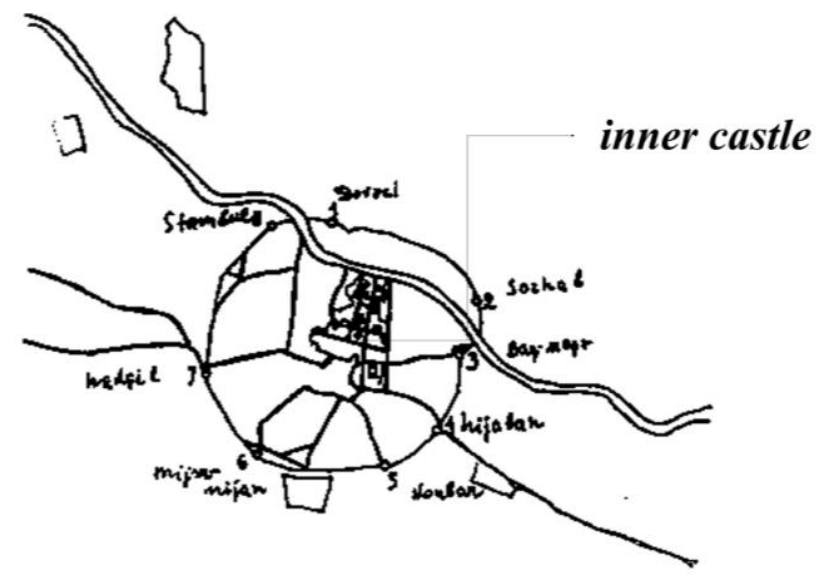

Figure 3. The plan showing neighborhood and city gates of the City of Tabriz (Useynov et al., 1963)

Thus, it can be noted that in the Middle Ages, the planning structure of this city was developed in an improper circular form, mainly around the palace of the Ruler. The palace complexes were located inside inner castles called "Shahristan" and around them, the city of Tabriz developed in the form of "sustainable development" (Figure 4).
In the Middle Ages, mainly in Muslim states, the palace complexes were located inside the inner castles called "Shahristan". Such buildings were found in many medieval Eastern states, one of which is the plan of Bukhara city of $9^{\text {th }}-10^{\text {th }}$ centuries (Arapov, 2013). Paying attention to the plan structure of the city of Bukhara, in the Middle Ages it also developed mainly around "Shahristan", that is, "Inner Fortress". 


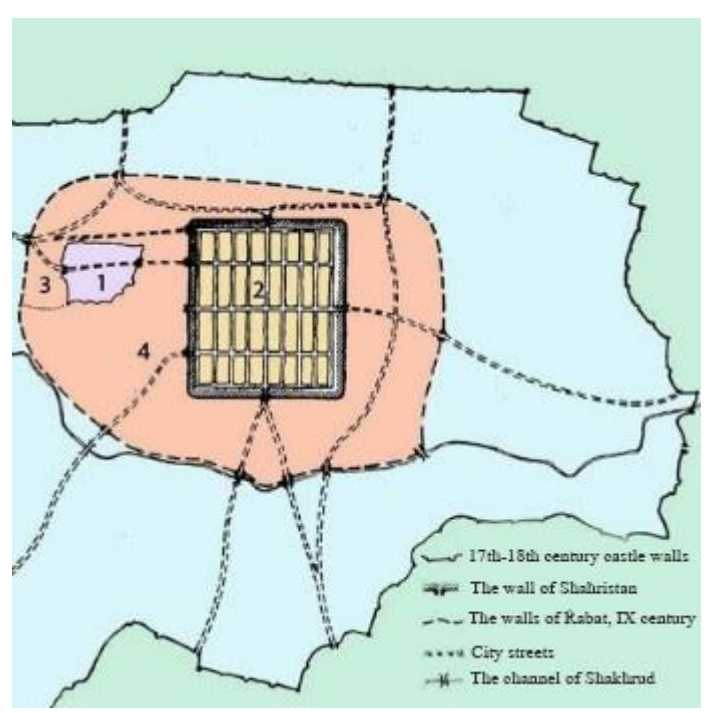

Figure 4. Reconstruction of the plan of Bukhara IX-X centuries. (G. E. On the basis of Correction of Bolshakov E. Davidovich): 1. Arc (fortress), 2. Shahristan, 3. Registan (central square of the city), 4-Rabad (trade and industrial center) (Arapov, 2013)

In general, when examining the plan structure of some cities formed in the Middle Ages, it is possible to see clearly in modern times that the dominant of plan structures, similar to the improper environment, was an inner fortress, that is, Shahristan, where the palace complexes were located. Although the walls of the castle were rounded, in many Eastern countries "Shahristans" were built in a rectangular shape (Muradov, 1984). Examples of such cities are Hamadan, Tabriz, Bukhara and Diyarbakir (Figure 5).
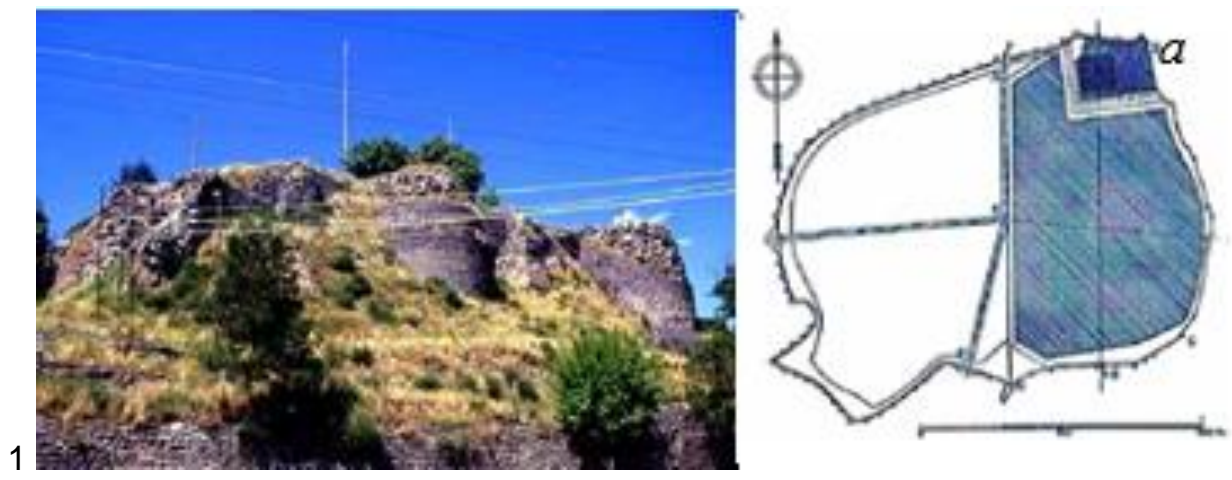

Figure 5. 1. Reconstruction plan of Diyarbakir, 2. a-Inner Fortress (Parla, 2005)

In the $16^{\text {th }}$ century, a palace was inside the inner fortress, according to the information given by travelers and researchers who traveled around Diyarbakir. In other resources, "Muslim shahzadas used to live in the palace located here in the past. The only foundation remains in this palace" is written and confirms the presence of the palace complexes inside the inner fortress (Aslanapa, 1962). In one of the inscriptions written on the inner fortress, "Artuklu Palace" belonging to the $13^{\text {th }}$ Century is confirmed to be erected here (Parla, 2005).
This proves that, in addition to being one of the main architectural forms of palace buildings in the Middle Ages, cities played a major role in the organization of the composition structure of the cities.

The rich history of Islamic architecture is proven by its well-known monuments in the world. The architecture of these monuments, characteristic to national traditions, the beauty and subtlety of ornaments have always been eye-catching. The richness of such monuments in our homeland Azerbaijan had left a mark in the World Architecture and interested scientists and many of their works 
had noted the architectural magnificence of these monuments.

\section{Similar Characteristics of the Palace Complexes of Medieval Muslim States}

Among such monuments is Shirvanshahs palace complex - the Pearl of Azerbaijani architecture, which was the residence of the Shirvanshahs state in the Middle Ages, was declared the state historical and architectural reserve-museum in 1964, considered as unique architecture and cultural complex, as well as its historical part surrounded by fortress wall of Baku included in the UNESCO World Heritage List. It was registered in 2001 by the Cabinet of Ministers of the Republic of Azerbaijan as a World-renowned architectural monument (Anonymous, 2019).

According to historical resources, the main buildings of Shirvanshahs palace ensemble were erected during the reign of Shirvan rulers Shirvanshah I Ibrahim (13821417) and I Khalilullah (1417-1465) (Useynov et al.,
1963) and they were built in a picturesque place at the top of one of the hills of the "Inner city" fortress (Figure 6). Almost all "Ichery Shahar" and Baku Bay are seen from the terrace in front of the complex. It should be noted that the development of Baku in the $12^{\text {th }}$ century is characterized by its transformation into an administrative center by the state of Shirvanshahs. During the reign of the Shirvanshahs in Baku, along with several defensive buildings, public and religious buildings were also built in the city. Even though the complex of palaces built by the Shirvan Shahs in $12^{\text {th }}$ Century did not reach our time, according to researchers, this complex was in the place of the present palace complex and in the $15^{\text {th }}$ century reconstruction was carried out there (Mammadova and Mammadova, 2013).

The Shirvanshahs Palace was built in a strategically convenient location within the inner fortress, focusing on the structure of the settlement plan within the fortress walls of the city. The selection of the place of construction of this building is based on the Islamic urban planning laws.
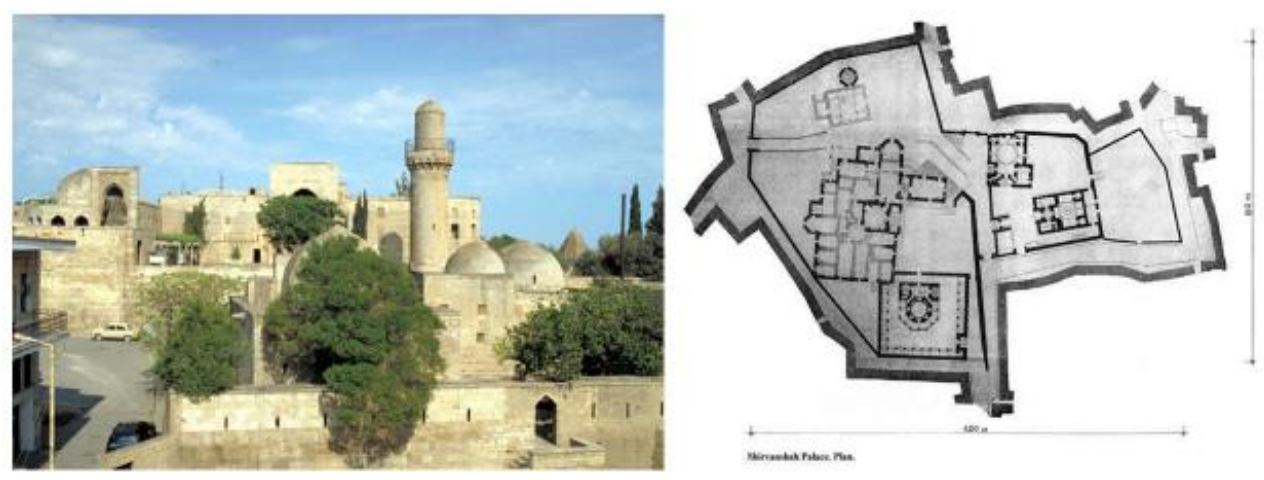

Figure 6. View and general plan of the Shirvanshahs Palace (URL-1, 2021)

The area of the ensemble was erected on a square with an area of about one hectare. This includes the palace, the diwankhana, Tomb of Shirvanshahs, palace mosque with minaret, the bath, the pool, the Seyid Yahya Bakuvi mausoleum and the later east entrance. In addition, along with the Mausoleum of Seyid Yahya Bakuvi there was Key-Kabut Mosque in the territory of the complex that had not reached modern times.

The complex configuration of the palace building, and the special layout of the rooms are the results of the construction of separate parts of the building, which determine some planning features at different times $\left(13^{\text {th }}\right.$ and $15^{\text {th }}$ centuries). The walls of the octagonal central hall differ greatly from the walls of the remaining rooms according to their thickness.
In the north-west corner of the palace, behind the stone fence built in the $15^{\text {th }}$ century, there was a diwankhana in the second courtyard. In the middle of the courtyard, an octagonal central pavilion was erected on a stylobate with the height of $1.5 \mathrm{~m}$. The central hall of the pavilion forwards to the open gallery from five sides. The western facade of the diwankhana was emphasized with a magnificent arch. Its ox-like alcove based on a complex stalactite system had been completed with a thin semidome.

In the southern courtyard, there is an octagonal tomb known as the mausoleum of "dervish" named after the famous palatial scientist Seyid Yahya Bakuvi, erected in the second half of the $15^{\text {th }}$ Century. The octagonal upper chamber embraces the dome neck, forming a three-centered curve. In the north wall of the tomb, there was an entrance gate that opened into the hall of the Key-Kubad 
Mosque.

The lower corner leads the yard through a simple and arched passage. In the depths of the courtyard, there is a Mausoleum of Shirvanshahs built in 1435-1436 years. The mausoleum has a smooth rectangular prismatic volume. The arrow of the eastern facade is embossed with a composition solution and decorative patterns of the arch.
Built in 1441, the palace mosque is in the southern part of the lower courtyard. It was completed with two domes and was shaded by the compactness of prismatic volumes and the well-formed vertical of the minaret, erected in the northeastern corner of the building. The mosque has two prayer halls, as well as several small utility rooms. On the south side, there is a simply decorated mihrab. Its shallow alcove is covered with an oxshaped semi-dome (Useynov et al., 1963).

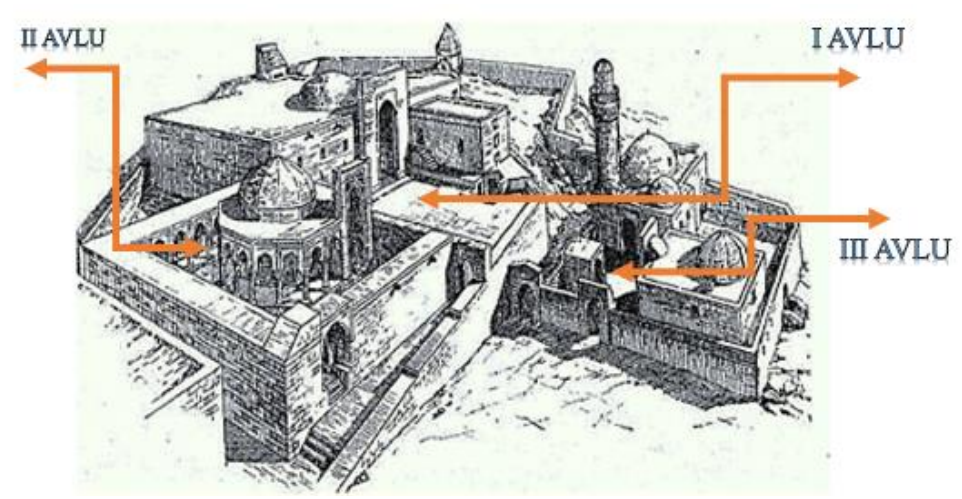

Figure 7. Overview of Shirvanshahs Palace complex (URL-2, 2021)

Some scholars note that the area where the complex is constructed has a hilly terrain (of 5-6 m difference), causing the formation of three small inner yards located in a distinctive altitude (Figure 7). However, when applied to World Architecture, in many of the palace architecture of Islamic architecture, which was built in the near $8^{\text {th }}-15^{\text {th }}$ centuries, similar buildings were grouped in one yard and the palace complexes was divided into three yards in most cases. For example, the palace building - a civil construction was built in the main yard, the memorial and religious buildings were built in another yard, the reception residence of the ruler (diwankhana) was built in another yard and the spaces were deliberately separated. The construction of such architectural complexes dates to the time when the Islamic religion began to spread. An example of such complexes is Jawsaq al-Khaqani and Balkuvara palaces built in Samarra in the $8^{\text {th }}$ and $9^{\text {th }}$ centuries, which were the early Abbasy palace complexes (Figure 8) (Brand, 2008).

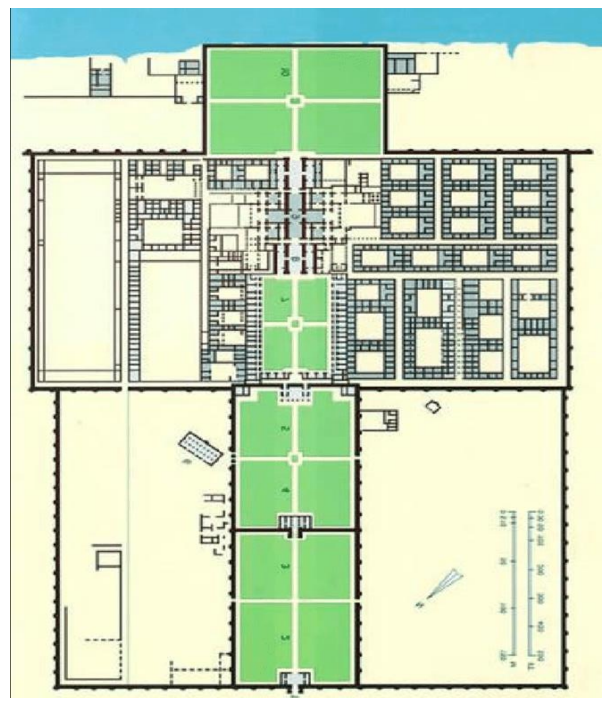

Figure 8. The layout of the palace of the Balkuvara (848-859 years) (URL-3, 2020) 
The arrangement of the three-part plan taken from Emevi palaces, which was placed behind each other in Jawsaq al-Khaqani and Balkuvara palace complexes, was considered in the closed center form (Voronina, 1969). The front view of Jawsaq al-Khaqani palace was made up of three balconies with three sharp arched facades of $11.1 \mathrm{~m}$ height with a parallel cradle vault. This showed that this palace had a facade of the three gardens. The dates of the construction of the palace of the Balkuvara are 854-859 years. The palace had a rectangular plan with an edge length of $1250 \mathrm{~m}$ and was surrounded by a wall with towers in its outer parts. The plan of the transverse rectangle is divided from inside into three parallel parts (Islamic Encyclopedia, 2016).

The architects thought that the layout of Jawsaq al-Khaqani and Balkuvara palace complexes belonging to the Abbasids built in the $8^{\text {th }}$ Century had three plans or three yards in the composition structures. In general, the fact that the number " 3 " in the religion of Islam contains many religious meanings and the existence, possibly the use of " 3 " figure in the layouts of these palaces complexes, even in the constructed form of the Shirvanshahs, Alhambra and Topkapi palaces built in the $15^{\text {th }}$ Century it not accidental. This shows that it could affect the structure of the forms, rather than relief yards in which the

\section{Shirvanshahs complexes located.}

The Topkapi Palace is one of the most magnificent examples of palace architecture built in the most beautiful place called Saray Burnu in Istanbul, which was the residence of the Ottoman Sultans until 1839 and has been functioning as a museum since 1924 (Azerbaijan Soviet Encyclopedia, 1979). The reason why we are investigating the architectural forms of this palace, which was built in the first period, is that it began to be built in 1466 almost in the same years as the Shirvanshahs Palace.

In contrast to the present Topkapi Palace, the smaller area of this complex included two palace buildings, an audience chamber, a "hazier", a castle wall and arches not included in the main complex (Figure 9). The Topkapi Palace Complex consisted of 700,000 square meters of land, 3 yards and lake-garden (Doghan, 2007). In the first yard, there was also a church, intended for the services of the palace and functioning as an armory. In the second yard, there was the shah's palace, the audience chamber and the "hazier" (the place with mosques and graves). "Hazire" was built between the second and third yards.

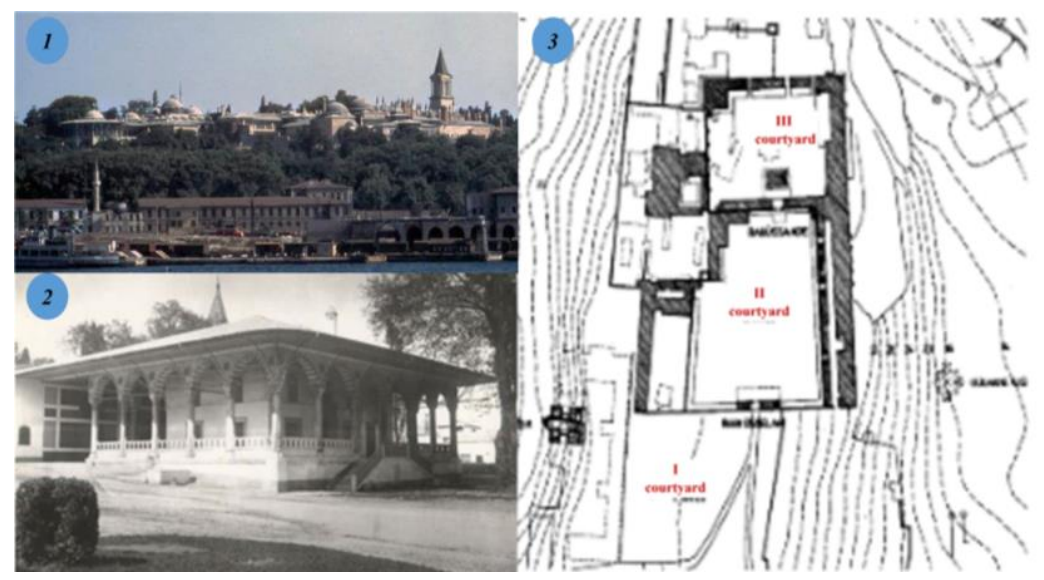

Figure 9. 1. Topkapi Palace, 2. Audience chamber (divan). (URL-1, 2021), 3. The layout of the palace built in the period of Sultan Fatih (Eldem-Ferdun, 1982)

The audience chamber (diwan) is considered one of the oldest buildings of complex. Here, the sultan had a magnificent room to welcome lawyers, military commanders and ambassadors. When looking at its architecture, it was built in the form of a pavilion surrounded by columns on four sides. The palace had two divans in common. Although the first diwankhana building was built in Topkapi Palace during the reign of Mehmed II, the present diwankhana building was built under the project of the palace architect Alsaddin during the reign of Suleiman the Magnificent (Eldem-Ferdun, 1982). Despite all this, both diwankhanas located in the complex are emphasized in the order of columns.

In contrast to Shirvansahs Palace, in which this complex was originally built, there are two palaces, the Audince, that is, the Divan was built in a courtyard with the Sultan's Palace, and the courtyard where the mosque and tomb were located was named Hazire (Eldem-Ferdun, 
1982). Despite this, it is like the fact that both palaces are chosen to be built in a suitable location from a strategic point of view and with the port view. It should be noted that this complex also consisted of three main buildings, such as the Sirvanshahs palace complex, and the similarity of architectural forms and designations of many buildings built here cannot be underestimated.
(Figure 10) (Doghan, 2007). Although the facades are different, this palace has many similar features with the Shirvanshahs Palace. When looking at the layout of the palaces, it can be clearly seen that both have a room with a central dome. In addition, both palaces have been arranged around the central salon. Such forms are mainly designed to illuminate the area.

One of the most ancient and interesting buildings of the complex is the "Chinili" Palace, which was built in 1472

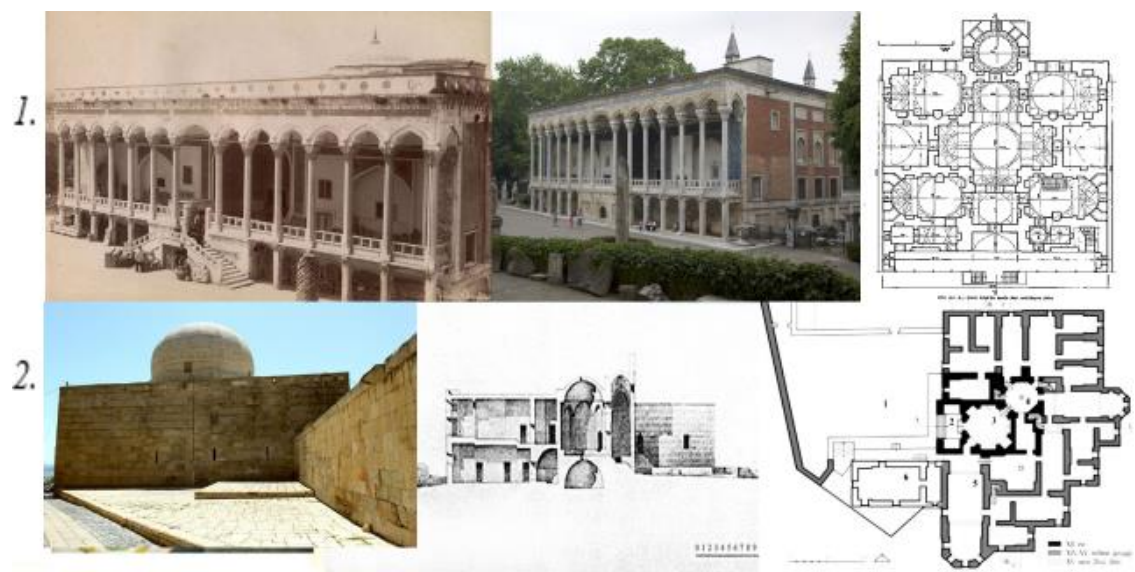

Figure 10. Chinili Palace; 1. General views of the palace and layout (URL-1, 2021), 2. Şirvanşahlar Palace building and layout (URL-4, 2020)

The palatial building of Shirvanshahs ensemble has a complex plan, which is explained by the fact that the complex is built on the highest relief. For this reason, the protrusion of the contours of the eastern and southern facades of the building, the asymmetrical absence of rooms from the floors, the absence of the transverse and longitudinal walls in the building, the octagonal shape of the central hall probably originated from the form of the relief. The octagonal shape of the Central Hall is already outdated in its layout, the Axitan Tower, named after Shirvanshah Axitan and destroyed by Mongolian catapults, and when the palace was built here, the remains of the tower take the form of eight-surface prism with deep ceiling, which was complemented by a dome with a high entrance port and was turned into a large vestibule (Ibrahimov, 2013). The study also emphasizes the absolute necessity of the central vestibule. The importance of the internal campus structure of the palace buildings forwarded to the center in those periods is an example of the plan structures of the Palace of the Sirvanshahs and the Chinili Palace of Topkapi complex.
In general, the reason for the existence of different aspects of Topkapi Palace together with the similar features with Shirvanshahs Palace, the main reason for the continuation of the construction of the Palace in the Middle Ages when the new ruler appeared in the Turkish state and there were many additional buildings. Nevertheless, the increase in the construction of the complex over the years has not disrupted its overall three-part layout structure. These include the inner garden, the external garden and the harem.

In addition to these, one of the architectural masterpieces of Spain, which is considered a pearl of architecture, as well as one of the most beautiful palaces of Islamic architecture is Alhambra Palace ensemble (Figure 11). This complex was also built during the reign of the Muslim Nasreddins dynasty (1232-1492) in the style of Moorish (1238-1273). Alhambra Palace ensemble was the residence of the rulers of Mauritania on the territory of Spain - the capital of the emirate of Granada (the middle of the $13^{\text {th }}$ Century to the end of the $14^{\text {th }}$ Century). The name of this monument in translation from Arabic means "Red Palace" (Bayon and Casals, 2014). 

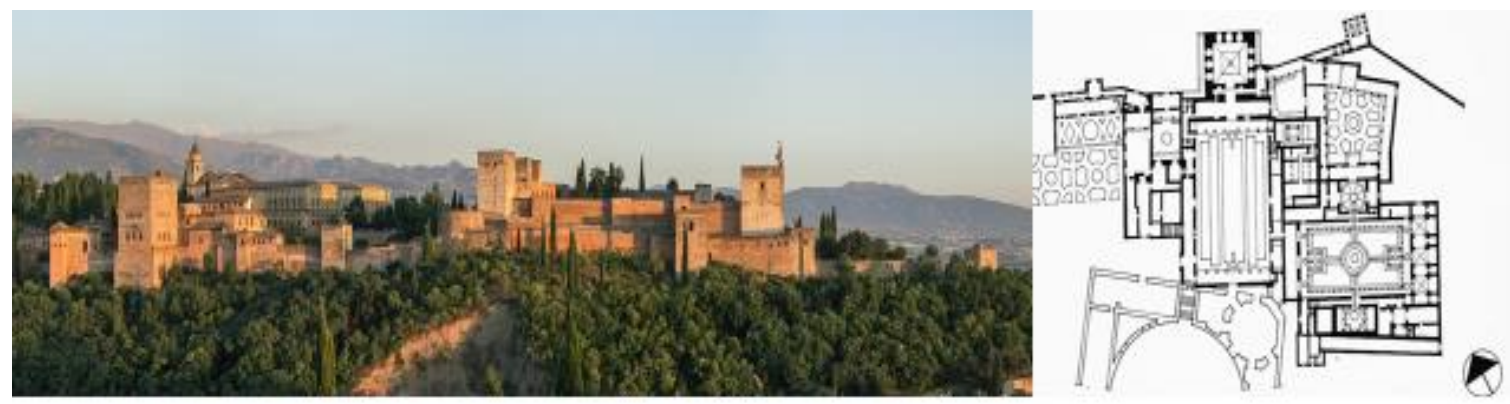

Figure 11. 1. Modern state and Alhambra Palace (URL-5, 2020), 2. Plan of the palace (URL-1, 2021)

The construction of the palace was carried out by the order of Muhammad Ibn Nasr in 1238. For its construction, the "Red Hill", the tallest hill of Granada, was chosen. The length of the hill on which the complex is built is $850 \mathrm{~m}$, the width is $240 \mathrm{~m}$. The buildings of Alhambra reaching to our time belong to the reign of Yusuf I (13331353) and his son Muhammad V (1353-1391), rulers of Granada in the $14^{\text {th }}$ century (Nizovsky, 2011). According to the planning period of this complex, it combined many innovations. The complex was formed based on a tradition of grouping of buildings around a courtyard typical of Middle Eastern architecture (Blokhina, 2014). In general, the "Alhambra" itself consists of courtyards, settlements, crossings and castles, each of which has its own initial designation and characteristics. This palace was named as the "Hall of Ambassadors", a hall decorated with rich patterns, created for Palace holidays of official ceremonies, "Hall of two sisters", "Court of the Myrtles", always decorated with green marble espalier with two internal staff, and the palace of the ruler "the court of Lions" for the freezing of twelve predatory statues around the fountain. "Hall of Abencerajes", "Court hall" and "Alhambra" adjacent to the most eastern part of the palace, the Torre de las Damas defensive tower with a pool and a small mosque. This complex consists of three sections, the advisory section where the ruler viewed the cases and received the people, the divan section for official receptions together with the throne hall and the harem section belonging to single women (Ibrahimgil, 2017).

If it has been looked at the architectural composition of the Court of Lions of this monument, the courtyard is surrounded with galleries, as it is in the courtyard of diwankhana of Shirvanshahs palace (Figure 12). The Court of Lions, which the construction dates to the $14^{\text {th }}$ century, consists mainly of 124 thin columns of porticoes on each side, pavilions on the sides and 12 statues of lions that hold the fountain's bowl. According to the legend, the throne of the Ruler Salmon was also hold by 12 lions (Blokhina, 2014).

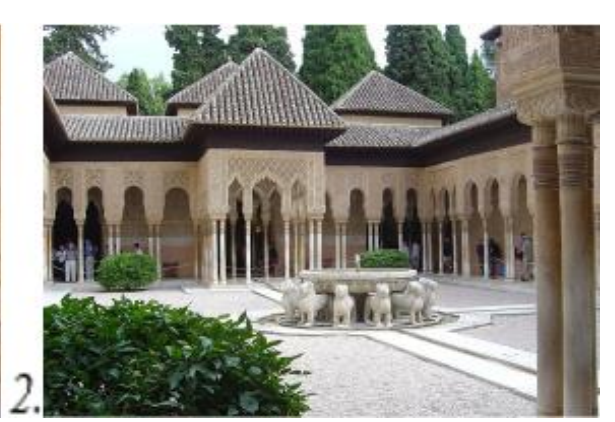

Figure 12. 1. Shirvanshahs Palace - Diwankhana (URL-6, 2021), 2. Alhambra Palace - Lions courtyard (URL-5, 2020).

The similarity of the general layout structure of this palace despite the differences in architectural styles from the previous ones and the similarity of the construction of this palace in one of the highest strategic points in the layout structure of the city, as in other medieval Islamic palaces, as well as the wide use of columns in the reception halls of the rulers were probably not accidental.
It would be very interesting to investigate the architectural features of the medieval palace of governors (an analogue of Shirvanshahs Palace ensemble), which is an example of Islamic architecture, and was considered a pearl of Indian architecture.

From 1569 to 1585, the capital of India, Fatehpur Sigrid, was a capital city, and a magnificent palace complex, 
built in this city as the residence of Emperor Akbar. This complex remains in a very good state until modern times (Figure 13) (Prokofiev, 1961).

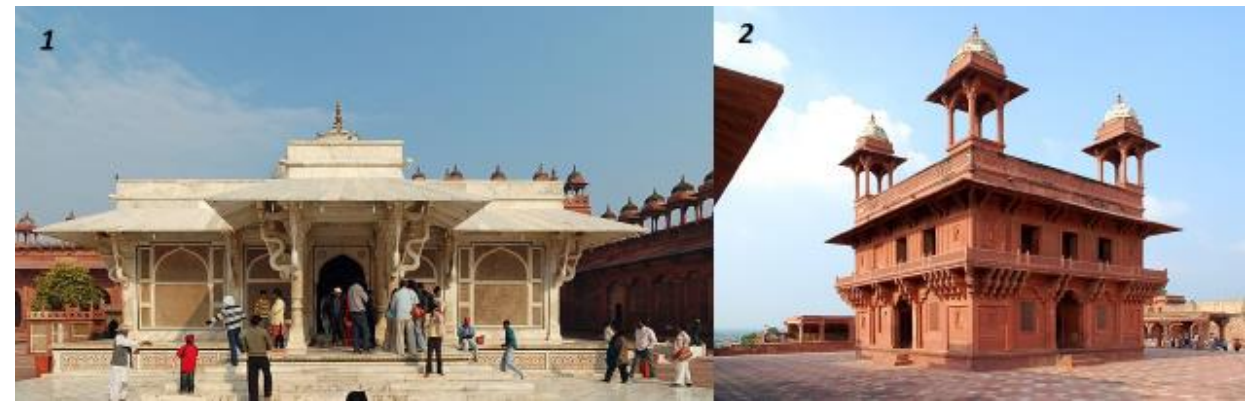

Figure 13. 1. The palace complex of the Mughal Emperor Akbar Shah, Tomb of Salim Chishti in Jama Masjid, 2. Divan-i-Am of the palace complex (URL-7, 2019)

Abu'l-Fath Jalal-ud-din Muhammad Akbar was one of the successors of Baburshahs Empire. The Mughal-Baburhahs empire was also considered the "Golden Age" of India. The reason for the construction of this city was that Salim Chishti, the creator of the Chishtia sect lived there and they respected him very much. The perimeter of the systematically planned fortress, on which the complex located is 14 kilometers, three sides of which are surrounded by fortress walls. There are nine castle gates and a very large artificial lake on one side (AliyevAyvazli, 2017). The main buildings included in this palace are Diwan-i-Am and Diwan-i-Khas, Ankh Mijhouli Pavilion, the palace of the Turkish Sultan, the District Palace of Panch daughter, Sonahra Makan Palace, Judh Bai Palace, Hava Mahal Palace, Birbala Palace, Juma Mosque, Boland Gate, Sheikh Selim Chisti, and Isa Khan's tombs, etc. In addition, a large mosque in the fortress covers a wide area, on three sides there are corridors. Two tombs were also built in the north of the mosque; one of the owners of them was Selim Chisti.

If we pay attention to the planning structure of this magnificent palace complex, there are also several inner courtyards, religious buildings and tombs, palace buildings and diwankhanas built in separate yards.

As in the Shirvanshahs Palace, the diwankhanas are open into the gallery, but there are two diwankhanas in this palace, of which the Diwan-i-Khas are intended for personal reception, and Diwan-i-Am are intended for public reception by the government.

Construction of two tombs in the courtyard of the mosque, as in the Shirvanshahs Palace, the tombs were built in the same inner courtyard as the mosque. In addition, it is important to note that the Tomb of Sufi Sheikh was built in this complex, which shows that palace culture influenced by Sufizm in the Middle Ages.

Some experts in their manuscripts mention the Shirvanshahs complex (Taghiyev, 2003) as a monumental or memorial building, comparing these complexes with religious buildings.

As to the attitude of this study, many tombstones were built in India in the Middle Ages and most of them are memorial mausoleums of the dynasty accepted Sufizm. For this reason, it is important to note that most of them were built under the influence of its architecture in the years after the construction of the diwankhana. The construction of the diwankhana dates to 1450 , and the diwankhanas of all the palace complexes analyzed in this study are observed in the order of galleries.

The construction of the Tomb of Humayun was started in 1565 and completed in 1572 (Figure 14). In 1544, Shah Humayun defeated by Afghan ruler Shirkhan in the battles and fled to Safavi I Tahmasib Shah with his wife and close relatives. During his stay in Tabriz, Humayun was closely interested in Azerbaijani architecture and art and admired its magnificence. Humayun wanted support from Tahmasib in the struggle for power. A few years later, Shah Tahmasib I sent 12,000 troops to India under the leadership of Commander Budag Khan Gajar, expelled the Safavid troops from Afghanistan, and Humayun returnede the throne of the Great Moghols. After regaining power, he invited a number of Azerbaijani artists to his palace in Delhi. Even the famous mugham "Mahur hindi" is supposed to be composed at the time of patronage Shah Tahmasib's Palace (Aliyev-Ayvazli, 2017). 

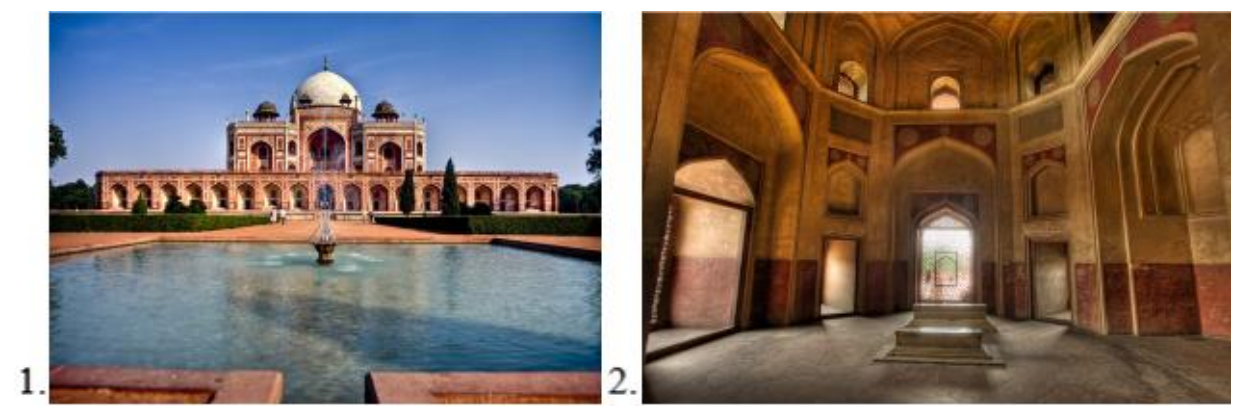

Figure 14. 1. General view of Humayun's Mausoleum, 2. Interior of the mausoleum (URL-8, 2019)

As it was said, Humayun became a great admirer of Safavid architecture after he left Azerbaijan. Taking this into account, Akbar Shah invited the Azerbaijani architect Agha Mirak Mirza Giyasi to India for the construction of a tomb built in Delhi for his father Humayun (1565-1569). Although the architects and masters of Humayun's tomb came from Samarkand and Iran, the main architect of the tomb was Aga Mirak Mirza (Aliyev-Ayvazli, 2017).

According to Indian art critics, this mausoleum was becoming a turning point in the construction of such memorial collections in India. The name of Agha Mirek Mirza Giyas, architect of the tomb built in memory of Shah Humayun, is written in golden letters in the history of Indian culture (Aliyev-Ayvazli, 2017).

Agha Mirak skillfully used the architectural forms that correspond to the best Safavid traditions in the architecture of this mausoleum. As is known, eight-storey buildings were built in Azerbaijan before and are considered common in the Islamic World.

It should be remembered that after the construction of the "Diwankhana" of the "Shirvanshahs" complex in the $16^{\text {th }}$ Century, the Azerbaijani architect Mirak Mirza Giyas was the architect of the Humayun mausoleum built in 1565 , which was considered an architectural monument of Indian architecture. When we examine the history of the construction of this mausoleum, we find very interesting information that the architectural features of this monument built in the architectural style of the Safavid period had a great influence on the Moghol architecture of India (Abasov et al., 2010).
As a prototype of Humayin's tomb erected by architect Mirak Mirza Giyas is the Taj Mahal Tomb (Abasov et al., 2010). The grandchild of Jahan Shah and Humayun Shah, who built the Taj Mahal, aforementioned Akbar Shah was the son of Humayun Shah. The similarity of all these architectural monuments can be explained by the fact that the architect of Humayin's tomb, the first building built, is Azerbaijani and has a very interesting history.

In general, when we examine the Indian Moghol architecture more deeply, we see its similarity with the buildings of many monuments belonging to the Shirvanshahs. One of these buildings may have an architectural form of the mausoleum built for the military commander-in-chief Adhan Khan in 1562 (Figure 15) (Anonymous, 2020).

This tomb was built in Indian architecture in the Afghan Lodi Dynasty style of architecture, and when examining the religious history of this dynasty they are also found to be from Sufi sect. Despite the differences in style, it is also doubtful that the structure of the general layout is like the Azerbaijani diwankhanas and is under the influence of Sufism, mainly symbolically. The history of the construction of this tomb dates to the Shirvanshahs. According to the Figures $19-21$, it is possible to say with certainty that the tomb of Adham Khan, built in India, is the closest contact of the Divan of the Shirvanshahlar complex, but it is inevitable that the architectural features of architecture are distinct from the point of view and architecture. More attention was paid to the architecture of Memorial buildings in the Middle Ages in India. 


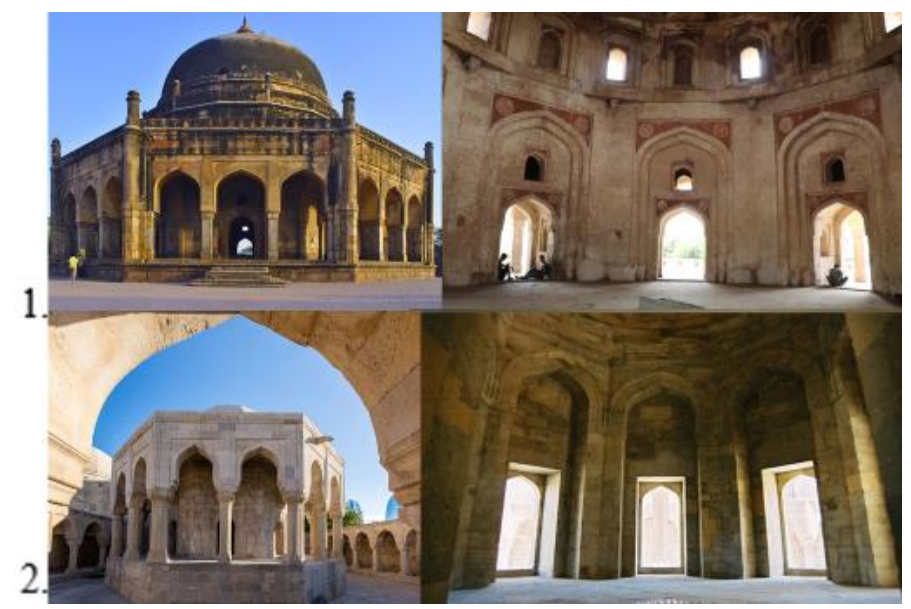

Figure 15. 1. Fragments of the interior of the Tomb of Adham Khan (URL-9, 2021), 2. Fragments of the interior of diwankhana of the Shirvanshahs Palace (URL-6, 2021)

In addition to all this, it may be considered appropriate to investigate the architectural features of another palace belonging to Islamic architecture. This is the palace complex Uhaydir (Kasru'l-Uhaydir), which is an example of Abbasi architecture. The palace of Uhaydir was built about $120 \mathrm{~km}$ south of Baghdad, in 778 by Khalifa AlMansur. It includes a mosque, a palace, a courtroom and a protective rectangular outer wall with a thickness 2.6 $\mathrm{m}$, a height $19 \mathrm{~m}$ and dimensions $175 \mathrm{~m} \times 169 \mathrm{~m}$ (Figure 16) (Ibrahimgil, 2017). When we look at the architectural structure of the palace court (Sharaf court) of Uhaydir palace diwankhana, it has been observed that the necessity of the presence of columns along the walls of the inner courtyard, where the court is located, as in the diwankhana of the Shirvanshahs, Topkapi, Akbar and Alhambra palaces (Voronina, 1969). In addition, the presence of a well inside the Diwankhana of Shirvanshahs Palace causes some scholars to make different judgments, but the presence of a well in the middle of the "Sharaf court" in the palace of Urhaida does not escape from eyes, and in fact it is confirmed that there is a place of conviction here.

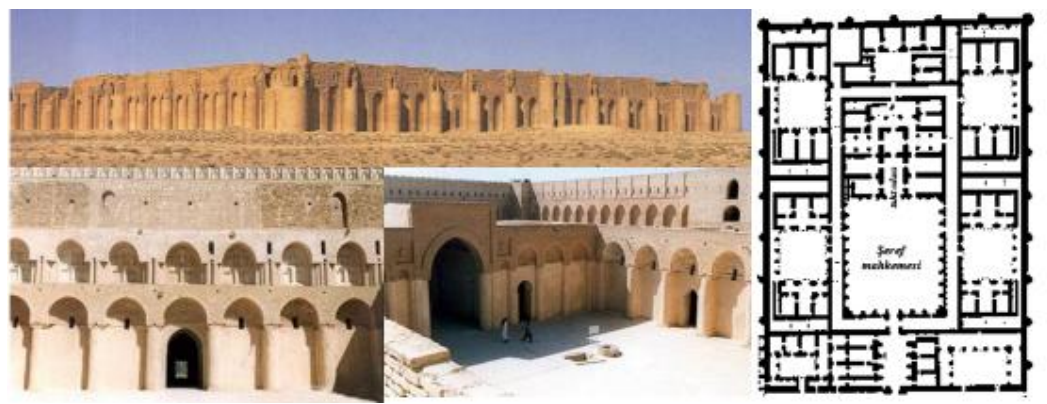

Figure 16. The King's Gate and the Charaf Courtyard of the Audience Hall of Uhaydir Palace (URL-10, 2019)

At the end of our research, it is important to note that the similarity of the architecture of these monuments built at the same time and their main role in urban development were not only close trade or religious ties between Muslim states, but also closely related to each other in their architecture.

\section{CONCLUSIONS}

In the Middle Ages, the plan structure of the cities was largely depend on the relief of the palace and the main buildings; i.e. the palace of the Rulers, were built in high places and the grouping of the main architectural masses determined the composition of the settlement of the central streets. This proves that, in addition to being one of the main architectural forms of palace buildings in the Middle Ages, cities played a major role in the organization of the composition structure of the cities.

According to all this information, almost all the palaces built in the Muslim-majority countries in the Middle Ages combined all the modern styles of the period, in addition to the Arabic style, using the national traditions of the places in which it is located, and became indispensable 
architectural monuments.

The above-mentioned medieval palace was built in a certain period $\left(13^{\text {th }}-17^{\text {th }}\right.$ centuries $)$ in Islamic countries urban planning and planning structure core, stylistic differentiation was reflected mainly in the facade and interior of the buildings, architectural planning structures and many forms of architecture were similar. As we mentioned above, all these palaces are united under the common Islamic architecture style, and the emergence of differences was the establishment of each palace under the influence of national architectural forms of the state in which it was built.

Such palaces are the Shirvanshahs Palace (Azerbaijan), Topkapi Palace (Turkey), Alhambra Palace (Spain), Akbar's Palace (India). Paying attention to the plan structures of these palace complexes located within the fortress walls of the city, it is found out that the influence of the palace complexes in the formation of the composition structure of the cities, where the architectural monuments studied in the Middle Ages, were located in the same direction.

\section{REFERENCES}

Abasov, A., Abasov, E. Huseynova, E. (2010). Islamic architecture and construction. Western University Publishing, Baku, Azerbaijan.

Aliyev-Ayvazli, B. (2017). Ethnography of India. Science and Education Publication, Baku, Azerbaijan.

Anonymous (2019). UNESCO World Heritage List. http://whc.unesco.org/en/list/958 (Access Date: 05.12.2019)

Anonymous, (2020). About Adham Han Tomb. http://www.wikiwand.com/ru//Гробница_Адхам-хана) (Асcess Date: 10.12.2020)

Arapov, A. (2013). Uzbekistan. In: The Artistic Culture of Central Asia and Azerbaijan in the $9^{\text {th }}-15^{\text {th }}$ centuries, Architecture. Samarkand-Tashkent: IICAS, Uzbekistan, 4: 160.

Aslanapa, O. (1962). The first reports from the Diyarbakır Palace excavation. Turkish Archaeology Magazine, 11(2): 1018.

Azerbaijan Soviet Encyclopedia. (1979). Chief editorial board of Azerbaijan Soviet Encyclopedia. Baku, Azerbaijan, 9: 314.

Bayon, F., Casals, L. (2014). La Alhambra de Granada. Triangle Postals, S.L. Spain.

Blokhina, I. (2014). Architecture, World History of Architecture and styles. AST LTD Publishing house, Russia.

Brand, B. (2008). Art of Islam. Grand-FAIR Publication. ISBN: 978-5-8183-1489-1. Russia.

Doghan, K. (2007). Ottoman architect. Yem-Yapı Publication, Turkey.

Eldem F., Akozan S.H. (1982). Topkapi Palace. Ministry of Culture and Tourism. National Education Publishing house, Turkey.
Gutnov, A., Glazychev, V. (1990). World of Architecture. Molodaya Gvardiya Publication, Russia.

Ibrahimgil M., Z. (2017). Art history Turkey. Koza Publishing, Turkey.

Islamic Encyclopedia (2016). Diyanet Foundation Publication, Turkey, 1: 51-53.

Kuruju, M., Ozen N. (2018). Matrakçı Nasuh on city-architecture and aesthetics in miniatures. International Art and Aesthetic Magazine, 1(1): 73-93.

Mammadova, G., Mammadova Z. (2013). The history of Azerbaijani architecture. Medieval architecture (VIII-XIV centuries), II volume. East-West Publishing House, Baku, Azerbaijan.

Muradov, V. (1984). Architecture and Art of Town Planning of Azerbaijan in XIII-XVI centuries. Academy of Sciences of Azerbaijan, Elm Publication, Azerbaijan, 15-26.

Nizovsky, A. (2011). 500 Wonders of the World. ISBN: 978-59533-3706-9, 978-5-4444-8066-3 Veche Publication, Moscow, Russia: 224.

Parla, J. (2005). Diyarbakir Castle Walls and City History. METU Journal of the Faculty of Architecture, 22(1): 57-84.

Prokofiev, O. (1961). Art of India and Southeast Asia. In: Art History. Art of the middle ages. Art Publication, Moscow, Russia, 2: 193-261.

Staradub, T. (2012). History of the Muslim World. In: History of art. Fedotova Y. (eds.), Russian Academy of arts White City Publication, Moscow, Russia, 1: 246-286.

Taghiyev, I. (2003). Shirvanshahs Palace and Seyyid Yahya Bakuvi Khanqah. Chasgioghlu Publication, Baku, Azerbaijan.

URL-1 (2021). Images of Topkapı Palace, Chinili Palace, Shirvanshahs Palace. https://archnet.org (Access Date: $01.01 .2021)$

URL-2 (2019). Overview of Shirvanshahs Palace complex. http://surakhani.cls.az/more/text/25247 (Access Date: 10.10.2019)

URL-3 (2019). The layout of the palace of the Balkuvara. https://www.sanatinyolculugu.com/balkuvara-sarayi/ (Access Date: 08.03.2019)

URL-4 (2020). Şirvanşahlar Palace building and layout. https://www.wikizero.com/az/\%C5\%9Eirvan\%C5\%9Fahlar\%C4\%B1n_saray_binas\%C4\%B1 (Access Date: 10.10.2021)

URL-5 (2003). Alhambra Palace - Lions courtyard. https://tr.wikipe-

dia.org/wiki/El_Hamra_Saray\%C4\%B1\#/media/Dosya:Alhambra-Granada-2003.jpg (Erişim Tarihi: 12.08.2019)

URL-6 (2016). Shirvanshahs Palace - Diwankhana. https://az.wikipedia.org/wiki/Divanxana_(\%C5\%9Eirvan\%C5\%9Fahlar_saray\%C4\%B1) (Access Date: 18.07.2019)

URL-7 (2019). The Salim Chishti Mausoleum of Akbar Shah's palace complex and the Divan-i-Am of the palace complex. https://en.wikipedia.org/wiki/Fatehpur_Sikri (Access Date: 08.12.2019)

URL-8 (2019). Humayun's Mausoleum. https://www.thousandwonders.net/Humayun\%27s+Tomb (Access Date: 20.12.2019)

URL-9 (2011). Tomb of Adham Khan. https://en.wikipedia.org/wiki/Tomb_of_Adham_Khan (Access Date: 20.12.2021) 
Importance of Palace Complexes, the Pearls of Medieval Islamic Architecture, in Urban Planning and Architecture

URL-10 (2005). Uhaydir Palace. https://muslimheritage.com/ukhaidir-palace/ (Access Date: 10.05.2019)

Useynov, M., Bretanitskiy, L., Salamzade A. (1963). History of Architecture of Azerbaijan. Architecture in Construction Publication, Moscow, Russia.
Voronina, V. (1969). The architecture of the Arab countries. In: General history of architecture. Literature in Construction Publication. Moscow, Russia, 8: 31-44.

Yurdaydın, G.H. (1963). Matrakçı Nasuh. Ankara University Publishing House, Turkey. 